\title{
Human Capital as a Base for Regional Development:
} A Case Study

\begin{abstract}
Submitted 23/02/19, $1^{\text {st }}$ revision 25/03/19, $2^{\text {nd }}$ revision 30/05/19, accepted 22/06/19
I.N. Sycheva ${ }^{1}$, O.V. Chernyshova ${ }^{2}$, T.A. Panteleeva ${ }^{3}$, O.A. Moiseeva ${ }^{4}$, S.A. Chernyavskaya ${ }^{5}$, S.Y. Khout ${ }^{6}$

Abstract:

Purpose: The main aim of this article is to consider the main trends observed in the labor market in the regional agricultural sector.

Design/Methodology/Approach: The study uses the statistical method, the method of analogy and comparison, as well as the positive and normative approach.

Findings: The study indicated that in the agricultural sector there are several problems associated with the formation of human resources. This is evidenced by the presence of negative trends that have been observed over the past 20 years. The main problems are the low educational level of workers, aging professional staff, and a reduction in the number of employees in all positions.

Practical implications: The socio-economic problems considered in the article indicate the urgent need to develop a mechanism of state support for agricultural workers.

Originality/Value: The authors define the concept of human capital and reveal the essence of the factors influencing its formation, revealing them from the perspective of the socioeconomic development of the region.
\end{abstract}

Keywords: Human capital, physical capital, labor potential, human potential, agriculture, quality of life, education, age, economic growth.

JEL codes: $013, Q 1, Q 18, R 11, R 58$.

Paper Type: Research article in Special Issue dedicated to Russian Economy.

Section 7: Economic Development.

\footnotetext{
${ }^{\text {I}}$ I.I. Polzunov Altai state technical university, Russian Federation, Barnaul, Russia. E-mail: madam.si4eva2010@yandex.ru

${ }^{2}$ Southwest State University, Kursk, Russia

${ }^{3}$ Institute of World Civilizations, Moscow, Russian Federation

${ }^{4}$ K.G. Razumovsky Moscow State University of technologies and management (the First Cossack University) (RAZUMOVSKY MSUTM (FCU)), Russian Federation, rektorat@mgutn.ru

${ }_{5}^{5}$ Kuban State Agrarian University named after I.T. Trubilin, Krasnodar, Russia

${ }^{6}$ Krasnodar Cooperative Institute (branch), Russian University of Cooperation

Krasnodar, Russia
} 


\section{Introduction}

The increase in labor productivity and the competitiveness of the modern market of agricultural products in the world market leads to an increase in the volume of agricultural production. Farmers are facing an acute problem of reducing the cost of production and increasing its quality. Achieving this goal requires both significant investments of physical capital and the use of human potential (Kuznetsova et al., 2019a; Kayumova et al., 2019; Pujiyono and Hutabarat, 2019; Asaliev et al., 2014; Masood et al., 2019; Monni et al., 2017; Bombiak, 2019).

Under current conditions, the production of goods and services depends not only on the use of advanced technology but also on the knowledge and skills of workers producing these products (Kuznetsova et al., 2018). Thus, in the modern world, a person with his/her knowledge, skills, and health acquires special value (Nikulin and Nikulina, 2017; Dobrovolskiene et al. 2017). Reforms occurring during the transition to market conditions have led to an acute shortage of skilled workers in the agro-industrial complex (Kuznetsova et al., 2019b; Arbidane et al., 2018; Mullakhmetov et al., 2018). This study is an overview and describes in detail the list of problems faced by the labor market in the agricultural sector.

\section{Literature Review}

Increasing the competitiveness of the agricultural industry depends on the degree of development of professional and non-professional competencies of employees. In modern conditions, the totality of knowledge and skills, as well as the degree of development of professional and non-professional competencies, is called human capital (Tarman, 2018; Mikhailushkin et al., 2018a; 2018b; Krasyuk et al., 2018; Lisin et al., 2018; Chitsaz et al., 2019; Pritvorova et al., 2018; Yigit, 2018). This definition has undergone significant evolution and as a scientific concept was formed in the middle of the 20th century. The development of this theory is associated with such famous surnames as Becker and Schultz. According to Becker, human capital is understood as a set of innate abilities and skills acquired over the course of a lifetime, the effective use of which will lead to an increase in income of the owner of human capital (Becker, 1964).

A special contribution to the emergence of the concept of human capital development was made by Simon Kuznets, who received the Nobel Prize in 1971. This economist was the first to link the degree of accumulation of national human capital with the transition of the economy to a new technological order (Kuznets, 1965).

\section{Methodology}

The object of the research is the human capital of organizations of the agrarian sector of the Novosibirsk Region. 
The subject of the research is the socio-economic relations that determine the theoretical and methodological foundations and principles of the formation of human capital (Astrauskaitė and Paškevičius, 2018; Lincaru et al., 2018; Kosorukov and Maksimov, 2016; Goloshchapova et al., 2018; Koptev et al., 2019; Malarev et al., 2018). The information base of the research work consists of the statistical compilations of the Federal State Statistics Service, orders of the Government of the Russian Federation, legislative acts and resolutions of the federal and local levels, as well as the results of empirical research and observations. The study used abstractlogical, design-calculated, empirical, monographic, and other methods of economic research.

\section{Results}

Currently, human capital plays a leading role in the formation of macroeconomic indicators. Turning to history, the degree of influence of physical and human capital on the economic growth of states was significantly different in different epochs (Table 1, Kuznetsova et al., 2019a).

Table 1. The degree of change in the structure of total capital in developed countries

\begin{tabular}{|l|l|l|l|l|l|l|l|}
\hline Years & 1800 & 1860 & 1910 & 1950 & 1975 & $1997 / 200$ & $2010 / 2016$ \\
\hline Physical capital & $79-81$ & $79-81$ & $68-71$ & $53-55$ & $44-45$ & $33-35$ & $18-20$ \\
\hline Human capital & $21-23$ & $23-25$ & $25-30$ & $50-57$ & $57-60$ & $68-71$ & $80-85$ \\
\hline
\end{tabular}

Thus, it is possible to say with a high degree of accuracy that the formation of human resources should be a priority in the implementation of the state program "Sustainable Development of Rural Territories". In the broad sense of the word, the concept of "sustainable development" can be defined as a form of socio-natural development that ensures the survival of humanity (country, region, territory) and the ability of its further sustainable (ongoing), continuous long development, so that future generations, as compared with the present one, have at least the same level of opportunities to meet their needs for natural resources and environmental conditions. Referring to the definition of this term, it is worth noting that according to Federal Law No. 131-FZ "On the General Principles of the Organization of Local SelfGovernment in the Russian Federation" dated October 6, 2003, "a rural territory" means "one or several rural settlements (settlements, villages, stanitsas, hamlets, khutors, kishlaks, auls and other rural settlements) having common territory in which local self-government is exercised by the population directly and (or) through elective and other bodies of local self-government".

In the authors' opinion, a rural territory should be considered as a territory of agricultural activity with the presence of the rural population, as well as social infrastructure objects that need to be developed as a combination of social relations and institutional entities (Dashko and Kotiukov, 2017; Fedorinin and Zhuravlev, 2002; Yemelyanov et al., 2018a; 2018b; 2018c; Zagrivnyi et al., 2019; Yemelyanov et al., 2019). It is worth noting that the current level of socio-economic development 
of rural areas does not meet the interests of the rural population and does not provide a decent quality of life for the rural population - carriers of the human capital of rural areas (Nechaev et al., 2018; Stoian et al., 2018; Sharafutdinov et al., 2017; Dmitrieva et al., 2017; Ponomareva et al., 2019a,b; Leonteva et al., 2018; Johnson and Hinton, 2019). This, in turn, has an extremely negative effect on the food security of the state.

The fact that rural areas are experiencing serious problems is indicated by the following facts related to the formation of labor potential. So, the first thing to emphasize is the aging of existing personnel. This is evidenced by the data presented in Figure 1.

Figure 1. The age structure of agricultural workers

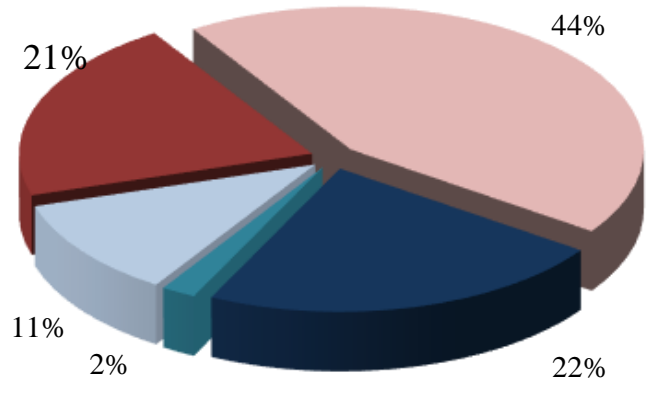

$$
\begin{aligned}
& 20 \text {-30 years } \\
& 30-40 \text { years } \\
& \\
& 40 \text { - } 50 \text { years } \\
& 50 \text { - } 60 \text { years } \\
& \text { over } 60 \text { years old }
\end{aligned}
$$

\begin{tabular}{|c|c|c|c|c|c|c|c|}
\hline \multirow[t]{2}{*}{ Population } & \multicolumn{7}{|l|}{ Years } \\
\hline & 1997 & 2013 & 2014 & 2015 & 2016 & 2017 & 2018 \\
\hline Total & 2725 & 2710 & 27311 & 2746 & 2763 & 2777 & 2799 \\
\hline \multicolumn{8}{|l|}{ Including: } \\
\hline Urban population & 2013 & 2110 & 2135 & 2156 & 2179 & 2193 & 2204 \\
\hline Rural population & 711 & 599.6 & 595.4 & 591 & 587.5 & 585.7 & 585 \\
\hline \multicolumn{8}{|c|}{ Share in total population, $\%$} \\
\hline Urban population & 73.9 & 77.9 & 78.2 & 78.5 & 78.9 & 78.9 & 79.1 \\
\hline Rural population & 26.1 & 22.1 & 21.8 & 21.5 & 21.1 & 21.1 & 20.9 \\
\hline
\end{tabular}

Secondly, there is a natural decline in the population living in rural areas. This is indicated by the data presented in Table 2 .

Table 2. The dynamics of the structure of the number of the urban and rural population of the Novosibirsk Region

As can be seen from Table 2, the population of the region grows annually due to the migration processes of the population from neighboring regions. This is because the region has significant economic potential. 
In addition to the outflow of the population from rural areas, there is a decrease in the share of the number of workers employed in the agro-industrial complex (Table 3 ). In 2017, the share of the population employed in the AIC was $7.4 \%$, while in 2012 this indicator remained at around $9.1 \%$. For 5 years, the decline in the number was $1.7 \%$.

Table 3. The dynamics of employment in agriculture

\begin{tabular}{|l|l|l|l|l|l|l|}
\hline Population & 2012 & 2013 & 2014 & 2015 & 2016 & 2017 \\
\hline Total number of employed & 1305.1 & 1348.7 & 1352.1 & 1365.6 & 1344.7 & 1326.5 \\
\hline Including in agriculture & 118.4 & 115.6 & 112.9 & 106.9 & 102.0 & 98.3 \\
\hline $\begin{array}{l}\text { The share of the population employed in } \\
\text { agriculture, \% }\end{array}$ & 9.1 & 8.6 & 8.4 & 7.8 & 7.6 & 7.4 \\
\hline
\end{tabular}

Thirdly, the share of workers with specialized education decreases. So, in 2017, the share of specialists with higher education was $55 \%$

Figure 2. Structure of education of workers in the agro-industrial complex

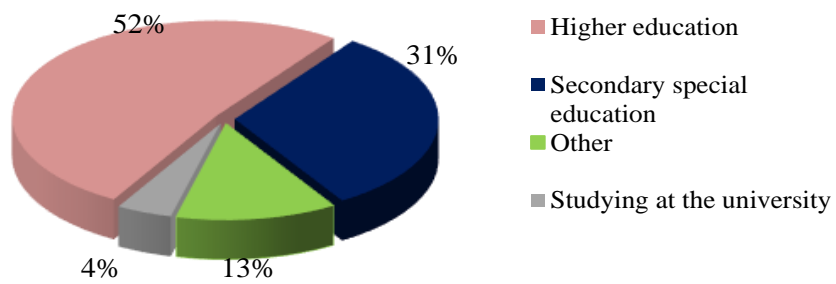

Fourthly, the proportion of employees who have undergone professional development and retraining decreases annually. To date, the motivation for advanced training among managers remains at a low level. Analysis of the data shows that the number of employees who have undergone retraining and advanced training decreases. So, in $2017,8.2 \%$ of specialists and $5.1 \%$ of managers underwent advanced training.

The analysis of the above-mentioned personnel problems in the industry indicates that the measures taken by the government to attract workers to agriculture are not sufficiently effective (Tereshin et al., 2001; Movchan and Yakovleva, 2019a; 2019b). A survey of graduates of agricultural institutions revealed the main factors that "frighten" potential specialists of the agricultural industry. According to graduates, their desire to work in rural areas is affected by: 
- low material interest;

- the unsatisfactory state of rural social infrastructure.

Let us analyze whether these factors correspond to reality. It should be noted that the average wage in the economy is 32,832 rubles while in agriculture the average wage is 18,366 rubles. The figure clearly shows that the incomes of agricultural workers are by more than a third lower than the average wage in the economy.

Figure 3. Incomes of workers of the agro-industrial complex

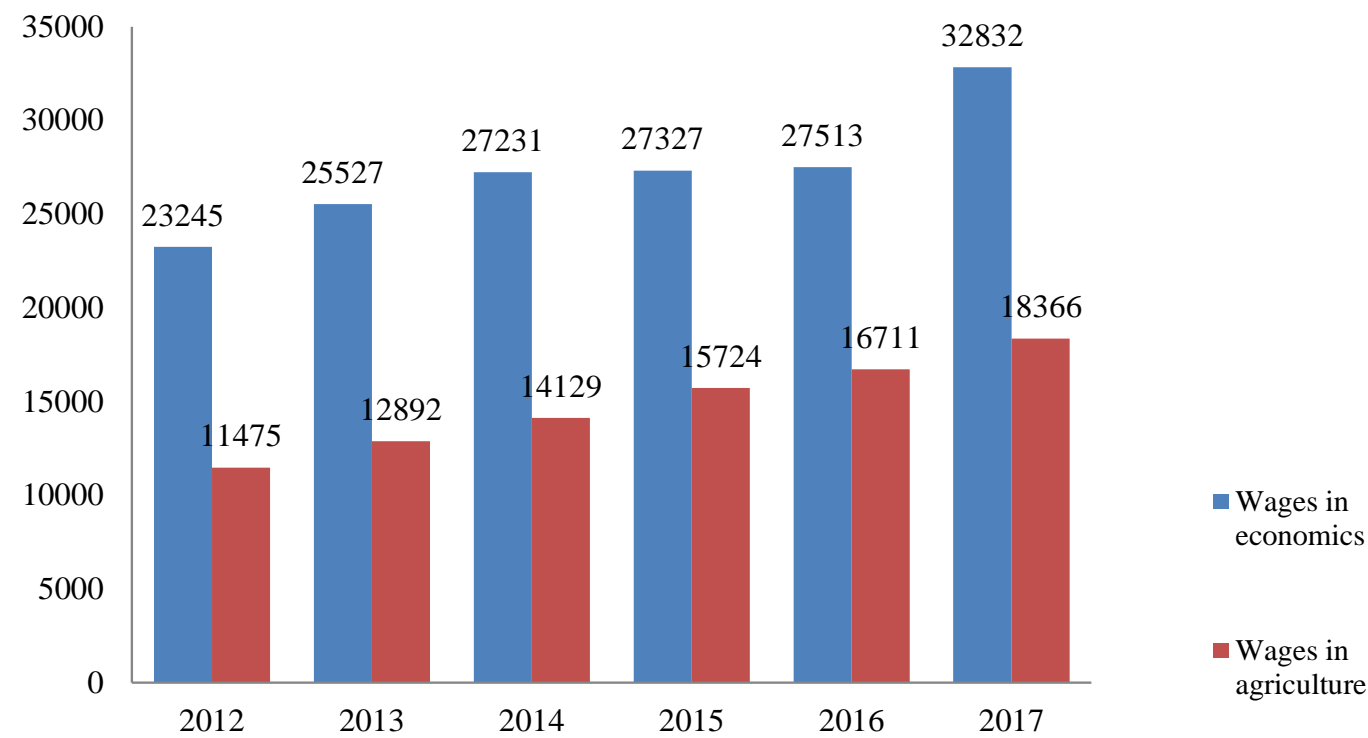

There are attempts to compensate for the low level of remuneration of young professionals by government support aimed at attracting young professionals to the industry. In accordance with the Law of the Novosibirsk Region No. 61-OZ dated December 8, 2006 "On State Support for Agricultural Production in the Novosibirsk Region" and the Resolution of the Government of the Novosibirsk Region No. 164-p dated April 15, 2013 (Shelkovnikov et al., 2018), graduates of secondary specialized education institutions can receive a lump-sum payment: young professionals who choose to work at organizations that are located at a distance of over $300 \mathrm{~km}$ from the city of Novosibirsk receive 30,000 rubles, and those who go to municipal units located within $300 \mathrm{~km}$ from the city of Novosibirsk - 20,000 rubles.

During the first two years of work, young specialists who work at organizations located at over $300 \mathrm{~km}$ from Novosibirsk are entitled to receive monthly payments in the amount of 4 thousand rubles, and those who work within $300 \mathrm{~km}$ from 
Novosibirsk -2 thousand rubles. For graduates of higher education institutions of the agrarian profile, the lump-sum payment is:

- 150 thousand rubles - to young professionals who have received higher education and got a job in an agricultural organization of the Novosibirsk Region during the first year after graduating from an agricultural education institution.

- 100 thousand rubles - to young professionals who have received secondary vocational education and got a job in an agricultural organization of the Novosibirsk Region during the first year after graduating from an agricultural education institution.

Within two years, the following monthly payments are provided:

- 6 thousand rubles - to young professionals who have received higher education and got a job in an agricultural organization of the Novosibirsk Region during the first year after graduating from an agricultural education institution.

- 4 thousand rubles - to young professionals who have received secondary vocational education and got a job within a year from the date of the termination of training in organizations engaged in agricultural production in areas of the Novosibirsk Region.

In addition to cash payments to young professionals who wish to move to rural areas, a subsidy is needed for building a house. This social benefit is provided subject to the following conditions:

- living in rural areas on a permanent basis;

- labor activity under an employment contract in rural areas;

- payment of a part of the cost of a land plot in the amount of at least 30 percent of the cost of this land plot;

- legislative recognition as being in need of improved living conditions.

The right to receive state social payments from the state authorities is granted to young professionals who choose the rural area as a permanent place of residence. The necessary conditions for obtaining social subsidies for young families are:

- moving to rural areas within the boundaries of the municipal territory in which one of the spouses carries out labor activities;

- living within the boundaries of the municipal district on the conditions of social hiring or renting, as well as other conditions established by the legislation of the Novosibirsk Region;

- registration within the boundaries of the municipal district in accordance with the conditions of the Russian legislation;

- the lack of ownership of living space in rural areas within the boundaries of the respective municipal district in which one of the members of a young family or a young specialist works; 
- last-year students of a professional education organization or higher education organization who have entered into agreements with an employer on employment in rural areas (Prodanova et al., 2017; 2019a; 2019b).

It is worth noting that young families and young professionals are provided with social payments in the amount of $70 \%$ of the estimated cost of housing construction. The payment of the state subsidy is established on the basis of the total size of the living space in square meters, established by law for all family members (33 square meters for one person, 42 for a family of two people, and 18 square meters for each member of the family exceeding 3 people).

Thus, the study shows that the state still carries out a number of measures to retain young specialists in rural areas. However, these measures are not enough for young people to change their minds and move to live and work in the countryside (Korableva et al., 2018). Therefore, further development of stimulating measures that can affect the final decision of young specialists is necessary.

\section{Conclusion}

One of the important factors affecting the efficiency of human capital formation, as well as the subsequent consolidation of workers in rural areas, is the quality of life and social protection of the population (Nikulin and Romanov, 2017; Stadnik et al., 2015). Most people living in rural areas have very limited access to the use of critical infrastructure, such as medical and educational institutions (Shelkovnikov et al., 2016).

In the authors' opinion, the formation of human capital in rural areas in order to increase the sustainability of rural areas should receive increased attention from public authorities. In the further development of the program relating to the socioeconomic development of rural areas, it is necessary to pay special attention to solving the problem of transport accessibility of municipal facilities, increase the accessibility of educational infrastructure and healthcare facilities (Rudoy et al., 2015). Summing up, the authors would like to emphasize that in order to increase the efficiency of using the personnel potential of rural areas, it is necessary to improve the remuneration of agricultural workers, which will lead to an improvement in the quality of life and solve the problems of outflow of the population from rural areas.

\section{References:}

Arbidane, I., Mietule, I. 2018. Problems and solutions of accounting and evaluation of biological assets in Latvia. Entrepreneurship and Sustainability Issues, 6(1), 10-22, http://doi.org/10.9770/jesi.2018.6.1(1).

Astrauskaitè, I., Paškevičius, A. 2018. An analysis of crowdfunded projects: KPI's to success. Entrepreneurship and Sustainability Issues, 6(1), 23-34, http://doi.org/10.9770/jesi.2018.6.1(2).

Asaliev, A.M., Zhuravlev, P.V. \& Alkhimenko, O.N. 2014. Intellectual capital management 
as the aspect of upgrading of modern company's management. Life Science Journal, 11(Spec. Issue 11), 363-366.

Becker, G.S. 1964. Human Capital: A Theoretiical and Empirical Analysis.

Bombiak, E. 2019. Green human resource management - the latest trend or strategic necessity? Entrepreneurship and Sustainability Issues, 6(4), 1647-1662, http://doi.org/10.9770/jesi.2019.6.4(7).

Chitsaz, E., Tajpour, M., Hosseini, E., Khorram, H., Zorrieh, S. 2019. The Effect of Human and Social Capital on Entrepreneurial Activities: A Case Study of Iran and Implications. Entrepreneurship and Sustainebelity Issues, 6(3), 1193-1203, http://doi.org/10.9770/jesi.2019.6.3(24).

Dashko, R., Kotiukov, P. 2017. Analysis of construction accident in saint petersburg based on consideration of underground space as a contaminated multicomponent system. Paper presented at the International Multidisciplinary Scientific GeoConference Surveying Geology and Mining Ecology Management, SGEM, 17(51) 67-74, doi:10.5593/sgem2017/51/S20.012.

Dobrovolskienė, N., Tvaronavičienė, M., Tamošiūnienė, R. 2017. Tackling projects on sustainability: A Lithuanian case study. Entrepreneurship and Sustainability Issues, 4(4), 477-488, http://doi.org/10.9770/jesi.2017.4.4(6).

Dmitrieva, I.S., Sharafutdinov, R.I., Gerasimov, V.O. \& Pavlov, S.V. 2017. Method evaluation of the human capital with its innovational potential consideration and perspectives of regional development: The example of the Republic of Tatarstan and Volga Federal District regions. Espacios, 38(40).

Fedorinin, V.N., Zhuravlev, P.V. 2002. New developments of optopolarization sensor devices and articles based on them. Paper presented at the Proceedings of SPIE - the International Society for Optical Engineering, 4900(2), 982-987, doi:10.1117/12.484491.

Goloshchapova, L.V., Plaskova, N.S., Prodanova, N.A., Yusupova, S.Y., Pozdeeva, S.N. 2018. Analytical review of risks of loss of profits in cargo transportation. International Journal of Mechanical Engineering and Technology, 9(11), 1897-1902.

Johnson, C. \& Hinton, H. 2019. Toward a Brillant Diversity. Journal of Culture and Values in Education, 2(1), 56-70. Retrieved from http://cultureandvalues.org/index.php/JCV/article/view/27.

Kayumova, G., Sheymardanov, S., Akhtarieva, R. \& Zhundibayeva, A. 2019. Developing creative potential of a schoolchild by means of native language. Journal of Social Studies Education Research, 10(1), 81-92.

Korableva, O.N., Kalimullina, O.V., Zaytseva, A.A. \& Larionov, A.I. 2018. Elaboration of database for the subject domain of innovation and economic growth potential. Paper presented at the Proceedings of the 31st International Business Information Management Association Conference, IBIMA 2018: Innovation Management and Education Excellence through Vision 2020, 6065-6073.

Krasyuk, I.A., Kobeleva, A.A., Mikhailushkin, P.V., Terskay, G.A. \& Chuvakhina, A.G. 2018. Economic interests focusing as a basis of the formation of investment policy. Espacios, 39(31).

Koptev, V.Yu., Kopteva, A.V., Poddubniy, D.A. 2019. Increase in Energy Efficiency of Oil and Gas Companies by Perfecting of Management Systems. Proceedings of the 2019 IEEE Conference of Russian Young Researchers in Electrical and Electronic Engineering, ElConRus, 548-552, Doi: 10.1109/EIConRus.2019.8657041.

Kosorukov, O.A. \& Maksimov, D.A. 2016. Methods of assessing efficiency of wildfire monitoring systems functioning. Research Journal of Pharmaceutical. Biological 
and Chemical Sciences, 7(6), 517-529.

Kuznetsova, I.G., Bulyga, R.P., Rakhmatullina, L.V., Titova, S.V., Shichiyakh, R.A., Zakirov, R.A. 2019a. Problems and Prospects of Human Capital Development in Modern Russia. International Journal of Economics \& Business Administration, Volume VII, Issue 2, 164-175.

Kuznetsova, I.G., Surikov, Yu.N., Votchel, L.M., Aleynikova, M.Yu., Voronkova, O.Yu. \& Shichiyakh, R.A. 2019b. The methodological aspect of human capital formation in the digital economy. International Journal of Mechanical Engineering and Technology, 10(2), 1020-1030.

Kuznetsova, I., Voronkova, O., Bakvalov, S., Ruiga, I., Zhuruli, G., Levichev, V. 2018. Formation of Human Capital as a Key Factor in Ensuring the National Security of Agriculture in the Digital Economy. European Research Studies Journal, Volume XXI, Special Issue 3, 73-83.

Kuznets, S. 1965. Economic Growth and Structure: Selected Essays, N.Y.

Leonteva, L.S., Maximov, D.A., Kurbanov, S.A., Afanasyev, I.V., Melnikova, T.E. \& Rezakov, R.G. 2018. Information services and development of effective urban management. International Journal of Civil Engineering and Technology, 9(11), 2518-2525.

Lincaru, C., Pirciog, S., Grigorescu, A., Tudose, G. 2018. Low-Low (LL) High Human Capital Clusters in Public Administration Employment - Predictor for Digital Infrastructure Public Investment Priority - Romania Case Study, Entrepreneurship and Sustainability Issues, 6(2), 729-753, http://doi.org/10.9770/jesi.2018.6.2(18).

Lisin, E., Kurdiukova, G., Ketoeva, N. 2018. Sustainability issues of territorial power systems in market conditions. Entrepreneurship and Sustainability Issues, 6(2), 1041-1052, http://doi.org/10.9770/jesi.2018.6.2(38).

Malarev, V.I., Kopteva, A.V., Koptev, V.Yu. 2018. Electric Power Supply System Development for Down-hole Electric Steam Generators to Produce High-viscosity Oil. International Multi-Conference on Industrial Engineering and Modern Technologies, FarEastCon., Doi: 10.1109/FarEastCon.2018.8602954.

Masood, O., Tvaronavičienè, M., Javaria, K. 2019. Impact of oil prices on stock return: Evidence from G7 countries. Insights into Regional Development, 1(2), 129137, https://doi.org/10.9770/ird.2019.1.2(4).

Monni, S., Palumbo, P., Tvaronavičienè, M. 2017. Cluster performance: An attempt to evaluate the Lithuanian case. Entrepreneurship and Sustainability Issues, 5(1), 43 57, http://doi.org/10.9770/jesi.2017.5.1(4).

Movchan, I.B. \& Anatol'evna Yakovleva, A. 2019a. Approach to automation of field diagnosis data interpretation for localization of pitting in the pipeline wall. International Journal of Civil Engineering and Technology, 10(2), 1571-1581.

Movchan, I.B. \& Yakovleva, A.A. 2019b. Wave analogies for generalized description of geodynamic zones. International Journal of Innovative Technology and Exploring Engineering, 8(6), 863-868.

Mikhailushkin, P.V., Lubkova, E.M., Shilova, A.E., Zhuravlev, P.V., Karpenko, E.Z. \& Nikiforov, S.A. 2018a. Possibilities of agriculture competitiveness increasing. International Journal of Mechanical Engineering and Technology, 9(11), 1401-1412.

Mikhailushkin, P.V., Novoselova, N.N., Shulga, K.V., Kolpak, E.P. \& Kabrits, S.A. 2018b. Study of the forms and conditions of economic crises in the regional economies of developing countries. Espacios, 39(31).

Mullakhmetov, K.S., Sadriev, R.D. \& Gabaidullina, L.A. 2018. Influence of human capital characteristics on transformation of management and control in the management of 
social and economic systems. Paper presented at the Proceedings of the 31 st International Business Information Management Association Conference, IBIMA 2018: Innovation Management and Education Excellence through Vision 2020, 3562-3572.

Nechaev, V., Mikhailushkin, P., Alieva, A. 2018. Trends in demand on the organic food market in the european countries. Paper presented at the MATEC Web of Conferences, 212 doi:10.1051/matecconf/201821207008.

Nikulin, A. \& Nikulina, A.Y. 2017. Assessment of occupational health and safety effectiveness at a mining company. Ecology, Environment and Conservation, 23(1), 351-355.

Nikulin, A. \& Romanov, A. 2017. Control over the use of personal protective equipment by employees, head protection. Ecology, Environment and Conservation, 23(1), 384389.

Pritvorova, T., Tasbulatova, B., Petrenko, E. 2018. Possibilities of Blitz-Psychograms as a tool for human resource management in the supporting system of hardiness of company. Entrepreneurship and Sustainability Issues, 6(2), 840-853, http://doi.org/10.9770/jesi.2018.6.2(25).

Ponomareva, N., Zvereva, A., Golubtsova, E., Novikova, E. \& Maximov, D. 2019a. Approaches to the improvement of tax auditing for operations with intellectual property in the russian federation. Espacios, 40(10).

Ponomareva, N.V., Zvereva, A.O., Golubtsova, E.V. \& Ilyashenko, S.B. 2019b. Tax incentives for use of alternative energy sources in the russian federation. International Journal of Energy Economics and Policy, 9(4), 144-148, http://doi:10.32479/ijeep.7964.

Prodanova, N.A., Smolentsev, V.M., Norkina, A.N., Shukshina, Y.A. \& Polyanskaya, O.A. 2017. Formation of system of internal control and features its functioning in the innovative development of industrial enterprises. International Journal of Applied Business and Economic Research, 15(13), 179-189.

Prodanova, N.A., Plaskova, N.S., Bochkareva, N.G., Babalykova, I.A., Gazizyanova, Y.Y. \& Zherelina, O.N. 2019a. Integrated Corporate Reporting as an Innovative Business Reporting Model. International Journal of Engineering and Advanced Technology, 8(5), 2075-2078.

Prodanova, N.A., Trofimova, L.B., Adamenko, A.A., Erzinkyan, E.A., Savina, N.V. \& Korshunova, L.N. 2019b. Methodology for assessing control in the formation of financial statements of a consolidated business. International Journal of Recent Technology and Engineering, 8(1), 2696-2702.

Pujiyono, Setiawan, F.A. \& Hutabarat, D.M.T. 2019. A new approach to preventing corruption in Indonesia: A study of the TP4 in Central Java, Indonesia. Journal of Social Studies Education Research, 10(1), 93-115.

Rudoy, E.V., Shelkovnikov, A.S., Matveev, M.D., Sycheva, N.I., Glotko, V.A. 2015. Green box and innovative of agriculture in the Altai territory of Russia. Journal of Advanced Research in Law and Economics, Vol. 6, № 3, 632-639.

Sharafutdinov, R.I., Gerasimov, V.O., Yagudina, O.V., Dmitrieva, I.S. \& Pavlov, S.V. 2017. Research of human capital in view of labour potential of staff: National companies case study. Paper presented at the Proceedings of the 29th International Business Information Management Association Conference - Education Excellence and Innovation Management through Vision 2020: From Regional Development Sustainability to Global Economic Growth, 839-852.

Shelkovnikov, S.A., Kuznetsova, I.G., Poddueva, I.S., Hodos, D.V., Yakimova, L.A., 
Ganieva, I.A. 2016. Regulation of the labor market and human capital in the agrulture of the Novosibirsk region. International Journal of Economic Research, № 9, Vol. 13, 3829-3845.

Shelkovnikov, S.A., Kuznetsova, G.I., Denisov, A.D., Peshkova, O.O., Malyshev, A.Y. 2018. Enhancing the instruments of state support for the process of building human capital. International Journal of Civil Engineering and Technology (IJCIET), Volume 9, Issue 8, 1633-1641.

Stoian, O., Polozova, T., Didenko, E., Storozhenko, O., Moskvichova, O. 2018. Strategies of interaction with a consumer within the marketing product policy. Entrepreneurship and Sustainability Issues, 6(2), 1018-1027, http://doi.org/10.9770/jesi.2018.6.2(36).

Stadnik, A.T., Shelkovnikov, S.A., Rudoy, Y.V., Matveev, D.M., Petukhova, M.S. 2015. Improving the methodology of disposition of state support funds for agriculture under the WTO rules. Asian Social Science, Vol. 11, № 14, 133-140.

Tarman, B. 2018. The Awareness of Social Studies Teacher Candidates' Regarding Special Area Competencies and the Overlap Level of These Competencies with Social Studies Degree. Journal of Ethnic and Cultural Studies, 5(2), 16-28.

Tereshin, E.A., Zhuravlev, P.V., Shatunov, K.P. \& Kosolapov, G.I. 2001. Research of possibility for nondestructive testing the cast core of joints of the grid spacers by thermal vision method. Svarochnoe Proizvodstvo, (4), 54-56.

Yemelyanov, V.A., Fatkulin, A.R., Nedelkin, A.A., Titov, V.A. \& Degtyarev, A.V. 2019. Software for weight estimation of the transported liquid iron. Paper presented at the Proceedings of the 2019 IEEE Conference of Russian Young Researchers in Electrical and Electronic Engineering, ElConRus, 381-384, doi:10.1109/EIConRus.2019.8657011.

Yemelyanov, V., Tochilkina, T., Nedelkin, A. \& Shved, E. 2018a. Automation of monitoring and diagnosing the technical condition of torpedo ladle cars. Paper presented at the MATEC Web of Conferences, 239, doi:10.1051/matecconf/201823904003.

Yemelyanov, V.A., Tochilkina, T.E., Vasilieva, E.V., Deeva, E.A., Nedelkin, A.A. \& Shved, E.V. 2018b. Information technology of monitoring technical condition of torpedo ladle cars based on neural networks. Paper presented at the Journal of Physics: Conference Series, 1118(1), doi:10.1088/1742-6596/1118/1/012051.

Yemelyanov, V., Yemelyanova, N. \& Nedelkin, A. 2018c. Diagnostic system to determine lining condition. Paper presented at the MATEC Web of Conferences, 172, doi:10.1051/matecconf/201817204001.

Yigit, M. 2018. Does higher education change value perceptions? Journal of Culture and Values in Education, 1(1), 1-8, Retrieved from http://cultureandvalues.org/index.php/JCV/article/view/5.

Zagrivnyi, E.A., Malarev, V.I., Kopteva, A.V. 2019. Studying the Operating Mode of the Down-Hole Electrode Heater for the Production of High-Viscosity Oil. Proceedings of the 2019 IEEE Conference of Russian Young Researchers in Electrical and Electronic Engineering, ElConRus, 1110-1113. Doi: 10.1109/EIConRus.2019.8656868. 